BEFORE / NOW

Vol. 1 No. 1

Labor Club, Vietnam War Demonstrations, July 4 , Arrests, Radicals (c) The Author(s) [2019].

Published by the Collaborative Research Centre in Australian History, Federation University Australia. All rights reserved.

\section{8: Victorian anti-war movement gets an injection}

\author{
Nicholas Butler
}

When the 'baby-boomers' had reached university age, their understandings, habits and behaviours often collided with the political discourse of their parents' generation. By 1968, the Monash University Labor Club, fresh from its campaign to raise money for the National Liberation Front of South Vietnam (NLF), had discarded the mantle of Labor reformism and set itself on a path of a radical communist activism that scorned the efforts of the Communist Party (CPA) to contain its enthusiasm. In concert with similarly leaning student clubs at the other two Victorian universities it turned its attention to the protest movement outside the university, against conscription and the Vietnam War. That brought the inevitable clash with the older established anti war movement led by a loose blend of ALP, CPA, church groups and unions. This process led, in Scalmer's classification of protest actions, to the mode of political demonstrations leaping radically from 'staging' to 'disruption.'

\section{Introduction}

With the ending of WWII, Australia entered a short period of popular enthusiasm, economic expansion and technological innovation which led in turn to a burgeoning consumerism and what is commonly called the 'baby boom'. This required a massive expansion of education and by 1968 these baby boomers had become young workers, apprentices and, for a substantial minority, students at university. That year is now commonly thought of as a high point in the 'youth revolt' that in many western countries rocked the established certainties of post-war capitalism and, in particular, shocked the proponents of the American war in Vietnam. The sharpest and most forceful revolt occurred in France but Melbourne students were no slouches in this regard. Leading the Melbourne insurgency was undoubtedly the radical cohort of Monash University students.

In 1968, the Monash Labor Club began to extend its operations from the University campus to the wider fields of anti-war and working class political activity. In doing so, the club's energetic radicalism exemplified and promoted a change in the nature and conduct of protest actions in Australia. The club's ideas developed rapidly in the conflict between the political motives and practical experiences of the older and more established peace movement versus those of the younger, newly radicalized militants - a conflict that played out in the planning and experience of anti-war protest actions.

Previously, in 1967, rather than the usually insular concerns of student politics, the Monash Labor Club concentrated on two major campaigns: firstly an insolent, highly publicised and successful campaign against the award of an honorary degree to Victorian Premier, Sir Henry Bolte whose government had just executed Ronald Ryan, the last person in Australia to be hanged. The second campaign concerned the raising of money for the National Liberation Front of South Vietnam (NLF), the 'enemy' in the Vietnam War. The uproar that followed raged for months in the press and prompted new federal legislation, the Defence Forces Protection Act (1967) that increased the notoriety of the club. 
Sean Scalmer ascribes these historical developments in physical protest as fitting a schematic sequence from 'staging' in the theatrical sense to 'contest' between protesters and authorities, most commonly police, and finally 'disruption,' that is, action which 'involves deliberate illegality of some kind ... or ... draws direct, reported, negative reaction from the police ... or ... prevents the routine use of a particular space by other actors." Scalmer estimates that in Melbourne, "By the early 1970s, many protesters had begun to embrace the new role of contestation.'2 Indeed, the stage of disruption had already been reached at Monash University in 1967 and in the streets by 1968.

\section{Monash Labor Club - Extramural}

With more than 300 adherents, anyone who wished to participate in its activities could be a Monash Labor Club member and rancorous ideological disputation within the club just had to be worked through. Even though the early constitution did stipulate that members would support the programme of the ALP and that membership of the Communist Party (CPA) was proscribed, there is no evidence that the rule was ever acted upon. CPA members were not quizzed nor were there any qualms about excoriating the Labor Party and its leadership.

Some of the Club's organizers had been members in the youth arm of the ALP, the Young Labor Association (YLA) but in the early years of 1966-68 members of the club generally had not brought set, party-political positions with them so the Monash Labor Club was their school of politics. Nevertheless, the main positions, represented at least fleetingly within the club from 1966 to 1969, can be identified as: the ALP's social democratic wing, many of whom identified with federal parliamentarian and contender for ALP leadership, Dr Jim Cairns; the CPA grouping around Mark Taft, son of the secretary of the CPA; Trotskyism of various tendencies; and an initially miniscule Maoist tendency that experienced 'snowball' growth to become the main and leading influence.

Political education of members proceeded from the needs of the club's various campaigns, which, particularly where they concerned the Vietnam War, moved the membership further and further towards the acceptance of socialist and communist ideas. Nevertheless, it bypassed both the liberal/social democratic ideals of the Labor Party and sidelined the CPA that seemed still to be limited by memories of Cold War attacks upon it. By 1968, after successfully challenging the authorities by raising money for the NLF, the promotion of revolutionary communism received little objection from members. For those members concerned about the apparent political blindness of such spontaneity, frequent articles on revolutionary politics in the Monash Labor Club's newsletter, Print, plenty of revolutionary literature at the Club's bookstall, and regular Friday night political discussions off campus in Caulfield (called the 'Caulfield Cong'), remedied the situation. In July 1968, the Monash Labor Club published its very first theoretical journal of political theory, Analysis, 'to raise the theoretical level of Monash Labor Club members and ensure that the experience we have gained in the course of agitational work is summed up and used to increase our political effectiveness.' ${ }^{3}$ The announcement in Print read:

Son of Print,

Birth Announcement ... Analysis, the Labor Club's theoretical journal has been born. Already it has repudiated its parent, Print and started producing serious articles. So if you're tired of Print's 'childish, rerelevant [sic] and extremist style' then... [contribute]... learned dissertation... ${ }^{4}$ 
BEFORE / NOW

Vol. 1 No. 1
Of those who joined the Monash Labor Club in 1966, Dave Nadel, Darce Cassidy and Albert Langer seem to have been the organising core. Cassidy had previously been active at Sydney University where he had been the secretary of the Sydney University ALP Club and editor of its newsletter, Wednesday Commentary. He had played an important role in the 1965 'Freedom Rides' campaign. It was as editor of Wednesday Commentary that he had developed the practice of 'guerilla journalism' that he brought to Monash University, editing the Labor Club's newsletter whose name he changed from 'Left Hook' to 'Print' for the first edition of 1967.

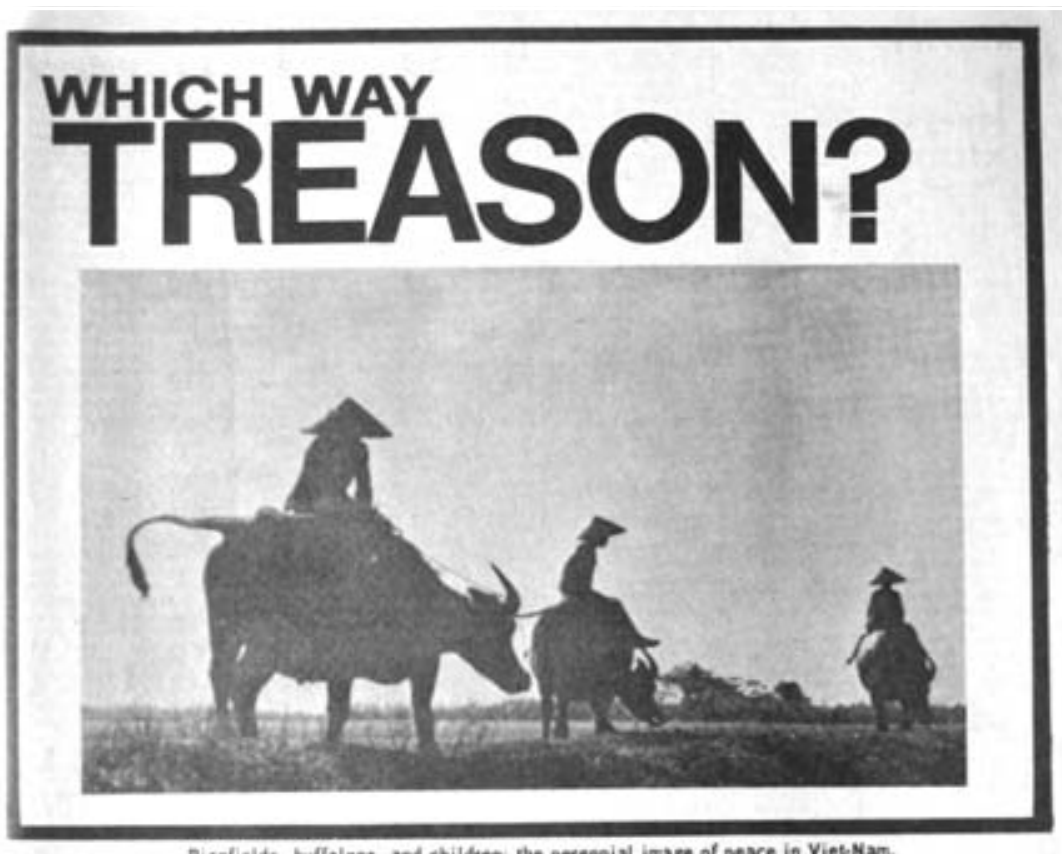

Ricefields, buffaloes, and childeten: the perennial image of peace in Viet-Mam.

- A pointed absence of American C.I.'s.

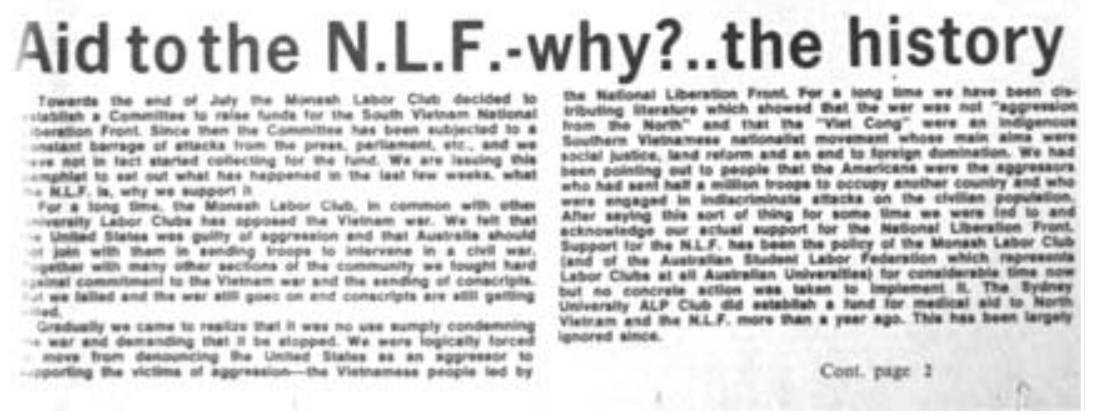

Committee for Aid to the National Liberation Front, Monash Labor Club, 1967. Author supplied.
Dave Nadel was also no stranger to political organisation. Since 1965 he had been a member of the Monash Labor Club, had been active in Young Labor and was aligned with Trotskyism, but he worked most closely with the Maoists. Albert Langer, aged 17 in 1966, had previously been involved in protest politics within the $Y L A$, and as an activist against apartheid. With his convincing writing and his oratorical powers he can be credited as early as 1967 for the club's adoption of its Maoist character.

According to one of the club's antagonists, 'The Monash Labor Club executive, by taking the initiative on almost every occasion, monopolised attention and formed the nucleus of an activist group of between one and two hundred'. ${ }^{5}$ The years of 1966, 1967 and 1968 also saw the Monash Labor Club's numbers amplified by a throng of capable student activists. Their frenetic campaigning consigned ideas of leadership contention to insignificance. There was just too much to do.

Activities of the Monash Labor Club during 1967 mainly occurred on campus and cooperation with other groups outside had been a minor aspect of its work. With developments in the Vietnam War and the continuation of conscription in Australia at the beginning of 1968, the club began to work out and argue for its political and practical stance in relation to other organisations in the peace movement. The contrast between the new and inexperienced, represented by the Monash Labor Club versus the more formal and experienced amalgam of church, union and peace groups that constituted the established peace movement, is well demonstrated in the comparison of two anti-war actions in 1968: the Sit-in Mobilisation in May and then the U.S. Independence Day rally on 4 July. 


\section{Into 1968}

New Year's Day 1968 promised very little. The Vietnam War continued, so did conscription; the Liberal Party remained in power and the anti-war movement, though heroically stoic, had little presence in the popular imagination. Then, on 31 January, the Tet Offensive in South Vietnam shattered the imaginings of war advocates and those who, like Gough Whitlam, had claimed that the war was winnable for the US and Australia. Ken Mansell, then a member of the Monash Labor Club has written,

To the Monash Labor Club, Tet represented a further indictment of the Gorton Government's position and a vindication of their own position. A revitalised anti-Vietnam [sic] movement advanced on a wider front with students taking up a leading position and using increasingly militant tactics of resistance. ${ }^{6}$

The needs of campaigns against war and conscription were complex and required plans, and solutions to be generated locally.

\section{Two protests}

Stirring into action, the peace movement organized a 'National Mobilization' (Against Conscription), to take place on Saturday and Sunday, 18 and 19 May. This was to be a mass 'non-violent sit-in' at the Prime Minister's residence, The Lodge. It aimed at having 'about 500 people from all states who are prepared to go to Canberra and allow themselves to be arrested.'7 Buses from all states would bring demonstrators who would arrive at least by 10am on Sunday May 19.

The stated aims of the mobilization were to force the government to:

a) release all conscientious objectors and refrain from imprisoning future conscientious objectors and draft resisters,

b) reject the proposed amendments to the National Service Act and

c) repeal the National Service Act. ${ }^{8}$

The mobilization highlighted the cases of draft resisters Dennis O'Donnell and Desmond Phillipson, both of whom had recently been incarcerated in the military prison, Holdsworthy, for their resistance to the draft. While Phillipson had claimed pacifist beliefs, O'Donnell simply based his case on the belief that 'the war in Vietnam is wrong in the same way that Hitler's war was wrong.'

The Mobilization's organising committee consisted of the Draft Resistance Movement, Melbourne and Monash Universities' pacifist societies and Labor clubs, Student Christian Movement, the Save Our Sons Movement (SOS) and 20 others. All were to follow 'civil disobedience' rules and were assumed to feel, 'strongly enough about this to be prepared to go to prison in non-violent, but effective confrontation. ${ }^{10}$ The message of passive non-violence was reinforced by two sets of instructions. The first, For All Demonstrators, set out the details of the assembly and 'procession' from Parliament House to the sit-in location at The Lodge. This included notes from 'Civil Disobedience Co-ordinator,' Michael Hamel-Green, that warned of agents provocateur and police who might goad demonstrators into '(a) intemperate statements; ... (d) excited or undignified behaviour; [and]...(f) mutual recrimination among leaders;' These notes further warned that if 'incidents do develop refrain from shouting or screaming at opponents and police and allow marshalls to handle the situation.' Then came a warning: 'There are not sufficient resources to pay the fines of those who provoke police or return provocations. ${ }^{11}$ While this form of action was quite different 
BEFORE I NOW

Vol. 1 No. 1

from that developed at Monash during 1967, the Labor Club held Michael Hamel-Green in high regard and it actively accommodated the tactic of passive resistance.

In Canberra, demonstrators received more warnings: They should already have 'considered the consequences to their careers and job prospects' and that when 'sittingin' at the front gates of The Lodge they must not spread 'out onto Adelaide Ave. in such a way as to impede the mainstream of traffic.' If the police took hold of them they should consider 'walking on your own feet to the police van [or] remaining limp all the way.' However, the latter of these two risked 'the additional charge of resisting arrest.' Once inside the van, demonstrators were urged to 'continue singing [and] talk quietly and reassuringly to any who have become distressed in the course of being arrested.'12

At the actual sit-in, hopes for a large number of arrests were realized, but not quite as expected. When the planned activities failed to excite police action the demonstrators became disruptive and spilled on to the roadway. The Canberra Times reported:

As about 50 of them sat in front of cars attempting to use the road, Inspector Kennedy told the Vietcong flag - waving, chanting demonstrators that they were committing a breach of the ACT Traffic Ordinance by obstructing traffic and that if they did not move he would have to order their arrest. The sitters sat firm.

'Arrest us', several shouted. 'That's what we came here for'.

An ACT police wagon was loaded with the first of the demonstrators who were picked gently from the ground, two or three policemen to each sitter, and carried to the wagon.

$\ldots$

As each demonstrator was removed another took his place until 69 had been arrested and sent to police headquarters to be charged. They included 20 women.

Co-operation between the police and the demonstrators reached its peak when the sitters began to walk voluntarily to the waiting vans.

'It's never been like this in any other demonstration I've ever been in', one student said as he waited to join the prisoners in the bus. 'It sort of takes the steam out of it'.13

This article, subtitled 'The Politest Protest', which took up the majority of page one, carried pictures of the sit-in but there was no reference to the aims of the demonstration, and the Vietnam War and conscription were mentioned only by their association with the words 'Vietcong flags' and 'draft dodgers."

The anti-conscription message did squeeze through on page seven of the same newspaper with a pictorial report of an earlier demonstration on the morning of the sit-in. It carried two photographs: one of a demonstrator with a Viet Cong flag and the other of demonstrators marching on the street in front of Parliament House carrying placards relating to conscription and advocating the release of draft resister Simon Townsend. There is one banner to be seen, that of the Monash Labor Club. ${ }^{15}$

The sit-in may have reaffirmed the resolve of the demonstrators but failed to raise media talk beyond the day after the protest. In the lock-up after their arrest, perhaps in an effort to salvage some publicity, the combined university Labor Clubs demanded, and got, the use of the lock-up as the venue for the opening of their conference. On page 1, the Canberra Times reported the student meeting in the same genteel manner as it had the whole demonstration: 


\section{STUDENT TALKS IN GAOL}

A spokesman for the Australian Student Labor Federation, which is due to begin its annual convention in Sydney today, said last night that as 38 of the delegates were in the cells they had decided to hold the opening sessions in Canberra - in. the lock-up.

The police provided a table and chairs. ${ }^{16}$

Also arrested were leaders of the Monash Labor Club, Michael Hyde, Albert Langer, Kerry Miller and Jill Jolliffe. Michael Hyde is reported as saying that 'Monash students had demonstrated despite proposed new disciplinary measures at the university which made the students liable to fines for "activities" prejudicial to the university."17 These 'disciplinary measures' were those that were to be applied in the wake of the 'Money for the NLF' campaign.

In Melbourne, The Age mentioned the demonstration in a similar fashion to the report from the Canberra Times. Its headline, 'Canberra sit-in puts 61 in gaol,' and leading article reported on the quaintness of the sit-in and missed the purposes of the action, saying that it was 'in protest against Federal legislation to close loopholes in the National Service Act.'

Of the 67 persons arrested, 32 came from Victoria and included Michael Hamel-Green to whose leadership can be attributed the organising of so many people to travel all the way to Canberra and take action, knowingly putting themselves at some risk. While this protest action failed to excite an extensive media response it nevertheless marks a transition from 'staging' to 'contest' and to 'disruption' as mode of protest. ${ }^{18}$

\section{July 4 demo’ 1968}

Upon their return to Melbourne, the Monash Labor Club set about creating headlines again, this time in the context of a demonstration in counterpoise to the July 4 celebrations of American Independence Day.

The fact that July 4 was a day when US officialdom promoted feelings of pride in the greatness of the 'American Dream' made it an obvious target for anti-war protest. Preexisting anti-war groups, such as the Congress for International Cooperation and Disarmament (CICD), had made use of the day in previous years but with little success. These older groups were made up of union, ALP, Church and CPA activists. They had large memberships of their own which were sustained by activities, services, staged rallies and the valiant work of canvassing and leafleting that suited and built their supporter base. They had little use for the type of outlandish activity that might get out of control and attract too much attention. To them, Sean Scalmer's notion that, 'Public interest was not won by a series of small, local actions but through a spectacular activity or a blaze of subsequent media coverage,,${ }^{19}$ would bring too many uncertainties. In the universities however, the situation was reversed.

The three university Labor Clubs, already in the process of breaking free from their Young Labor origins, had transitory memberships that relied on activity for the attraction of new members and the sustenance of current cohorts. ${ }^{20}$

\section{7 precursor}

The July 4 demonstration of the previous year, 1967, had been an archetype of the form of protest that belonged to the era prior to the advent of mass media. Arranged as if to avoid the 'spectacular activity' of which Scalmer wrote, ${ }^{21}$ it had been tightly organized by the 'Vietnam Day Committee'. It consisted of an Independence Day vigil 
BEFORE I NOW

Vol. 1 No. 1

and rally on the theme of Independence for All. The vigil was to begin on July 3 , continue overnight until a mass demonstration on July 4th between 5.00pm and $6.30 \mathrm{pm}$, which would then march to the Assembly Hall in Collins Street for a rally at 8.00pm. At the Assembly Hall, Senator J. Keeffe, Dr. Jim Cairns MHR and Francis James, the managing editor of the Anglican newspaper, addressed the crowd. For further activity, the Vietnam Day Committee urged the writing of letters to the US Consul Mr. W. Wieland. ${ }^{22}$

The demonstration took place as planned but media interest was not apparent. On the next day the Melbourne dailies, Herald, Sun and Age carried no reports of it at all. However, Vietnam was mentioned in a related context: Sir James Plimsoll, the secretary of the Department of External Affairs had, as guest speaker at the American Independence Day luncheon stated, 'Australia and America were not simply trying to win the war or preserve Vietnamese independence. "We stand for something much wider - the establishment of independence and security throughout South-East Asia' said The Age which obviously saw war affirmation as the more newsworthy event. ${ }^{23}$

\section{Something in the air}

For the 4 July 1968 morning issue of Print, Michael Hyde left nothing mysterious in its lead article, 'ROLL UP FOR THE MAGICAL MYSTERY TOUR' about the demonstration that was to occur on that afternoon:

Melbourne will see the biggest demonstration against the US international Police State since Johnson had the audacity to show his face here. Poster carrying processions are out - crash helmets are the order of the day. The American Embassy is to be held in siege, and ...

But seriously folks, Bolte's brutes (yes the cops) are bound to resent this ... So come protected. Leather and helmets are recommended. Girls wear bras, slacks and tie up your hair. But most important of all come....

It begins at 4.30 outside the American Embassy opposite the Chevron ... a bus will be travelling to it from the Monash - book at the Labor Club bookstall ... ${ }^{24}$

The emphasis here was upon active defensive measures, an implication that resisting arrest was quite in order, and that violence to a building or flag was quite in order.

As well as the pages of Print, the Monash Labor Club mustered student participants for the event in the traditional ways of posters, leaflets, meetings, and through other student organisations. For the event itself, smoke bombs and paint bombs were constructed, sky-rockets were purchased, tombowlers for the horses, and thick, wired up doweling for the tram tracks were prepared. ${ }^{25}$ Students from the other universities prepared similarly. Provision for bail money was made. Other anti-war organisations, including some unions and the CICD led by Sam Goldbloom, prepared also, but without the paraphernalia.

The U.S. consulate was a single storey building with very large plate glass windows partly protected by shrubbery. This is shown in the film that the Australian Security and Intelligence Organisation (ASIO) made of the arrival of demonstrators. This particularly concentrated on members of the CPA and very few students are shown. At that time, the objective of ASIO was to record only the comings and goings of known communists so their film was shot from a hidden position in the Chevron Hotel opposite. ${ }^{26}$ In the film, the shrubbery and gathered members of the CPA contingent are clearly visible but few students and young people are seen. 
The massed demonstrators completely blocked Commercial Road in front of the consulate and there was much milling about as leaders of the various peace groups attempted to be heard. Crowds surged back and forth and skyrockets added to the spectacle. As the daylight dimmed and smoke from the home made smoke 'bombs' began to swirl, a posse of mounted police rode at speed, long batons swinging, into the crowd and sometimes spinning the horses around for maximum effect. The Age reported,

For the first time in 25 years, mounted troopers last night were ordered at full canter into violent crowds in front of the U.S. Consulate-General in Commercial Road, Prahran.

The horses, rearing and frothing from fright sent men and women reeling to the bitumen. Other people were trampled under foot by protesters as they tried to escape the horses.

The horses charged into the crowd at least a dozen times to the aid of police fighting savagely with demonstrators close to the building. ${ }^{27}$

In the noise and spectacle and from the cover of the crowd, missiles and stones were hurled with sufficient force to smash some of the large glass windows. The next day, the Herald reported on the damage: 'At least 18 holes pockmarked the glass façade ... a large blotch of red paint over the front entrance showed where a paint bomb hit it. The glass damage is so extensive that ... almost the whole of the glass front will have to be replaced.'28 Wharf worker Dave Rubin successfully confiscated the US flag but suffered arrest for it.

The Age asserted that some groups of people 'tried to get near the building with four gallon cans of petrol ... [and that police had] 'confiscated four large cans.'29 Many demonstrators were arrested (none was charged with arson) and bundled into waiting divisional vans, most of which were then surrounded by protestors, some sitting in front of the vans and calling for the release of the prisoners. By this time, the demonstration was a mêlée with leaders of the various organising groups issuing contradictory calls for order or action.

Soon, it was pointed out that those arrested were to be taken to the Russell Street Watchhouse. Very quickly, the road at the consulate emptied as a march proceeded down the middle of the main road, St Kilda Road, through the city and via the U.S. owned Southern Cross Hotel where another confrontation with police led to further arrests. From there the march, numbering about 1000 protesters, proceeded to the Russell Street police headquarters where those arrested had been taken for processing before their transfer across the road to the Watchhouse. The crowd milled about and had the appearance of, if not the reality of, an attempt to rush the doors en masse. The police were ready and more arrests were made. The Age reported: '500 demonstrators tried to storm Russell Street police headquarters ... [where] ... police armed with batons charged the demonstrators to break them up. Demonstrators both men and women and police emerged from the riots covered with blood and with torn clothes. ${ }^{30}$

The Sydney Morning Herald reported the second demonstration in more detail:

A wild march by about 1,000 demonstrators from the consulate into the city started about 5.30 p.m.

By the time they reached Flinders Street their numbers had swelled to about 2,000. -- Rocks were hurled at the City Watchhouse and Police Headquarters as police fought to clear the area... Students charged the Watchhouse, punching and battering police with placards and flags. 
BEFORE I NOW

Vol. 1 No. 1

In the wild melee that followed, demonstrators, many of them women, and police were knocked to the ground as mounted police charged through their ranks.

After about 10 minutes they were finally forced into La Trobe Street and flanked by about 100 policemen, they marched to Assembly Hall... ${ }^{31}$

The next day's newspapers reacted as expected and as planned. The Melbourne Herald front page included: 'Rylah to police: you must get tough,' and 'Fine Not Paid - Student Gaoled,' on page three. On page nine the article, 'Stop Govt. aid to student rioters say RSL and DLP;' contained reactions from the Prime Minister, John Gorton, the leader of the Country Party, George Moss, the Returned Soldiers League (RSL) and the state secretary of the Democratic Labor Party (DLP) Jim Brosnan. ${ }^{32}$

Reportage of this demonstration continued at length in the two major daily newspaper groups. ${ }^{33}$ For example the Age of 9 July carried the front-page article 'PM acts to "tame" protesters' and on 10 July, under the heading, 'The Student Revolt' in a page three special section, 'Govt. checks powers on mob violence.' In the same edition, the letters page had half of its space given over to the matter. ${ }^{34}$ For the media this was a topic that would sell newspapers, but for the radicals it was a challenge to the state that would carry their message that the continuation or expansion of the war would bring only trouble.

To that end, the choice of venue for the demonstration had been important. Parliament House or the City Square would have missed the Labor Club's point that the U.S.A. was the source of the war. ${ }^{35}$ Outweighing the disadvantage that it was several kilometres from the city and transport centres, the U.S. Consulate signified this most forcefully. Television and the print media could not avoid mentioning the reason the consulate was under attack when it was engulfed in placards, banners, NLF and North Vietnamese flags - the Melbourne Age: 'Wild mobs storm U.S. consulate' and 'U.S. Flag Burnt;' as well as the Sydney Morning Herald, with a picture of the events at the consulate and noted, 'rioting crowd outside the American Consulate.' In the Australian Capital Territory, the Canberra Times diverted attention to the Monash Labor Club with, 'The demonstration had been quite peaceful until busloads of the Monash mob arrived,' but still could not avoid mention of the USA and the war. ${ }^{36}$

\section{Repercussions keep the issue alive}

In the public mind, associating protesters with opposition to the Vietnam War had been building over several years and this demonstration confirmed that association by co-opting both the moderates and even pro-war antagonists. When 'moderate' Labor MHR, Jim Cairns' stated his opposition to demonstrator violence this still signified the war simply because of his anti-war fame. ${ }^{37}$ Antagonists of the demonstrators did likewise, for example 'Stop Govt. aid to student rioters - say RSL and DLP.'38 Both of these organisations, The RSL and the DLP were such well-known supporters of the Vietnam War that their mention in the media in association with 'protester' or 'student' or 'demonstrator' signified 'Vietnam War'.

The federal Liberal Country Party government, having failed to take decisive action over the collection of money for the NLF, was keen to appear active this time. When Sir William Hall, president of the RSL, demanded that 'taxpayers' benefits received by university students should be revoked if students were convicted of serious offences as a result of demonstrations', the Prime Minister, John Gorton, 'told the Federal Attorney-General, Mr. Bowen, to consult urgently with States to prevent further violence.'39 By 9 July, the Age newspaper reported, 
PM acts to 'tame' protesters. [Headline]

CANBERRA. - Federal action to curb mob violence by demonstrators will be planned by the Prime Minister (Mr. Gorton.) and the Attorney-General (Mr. Bowen) this week.

Mr. Bowen will fly to Canberra for discussions with the Prime Minister in a day or two... ${ }^{40}$

However, the protests spread and by the end of the week there had been demonstrations in every state capital including Hobart where 'police dragged 50 demonstrating students from a sit in in Hobart's Department of Labor and National Service offices.' In Sydney, 'blows were exchanged when demonstrators tried to block the path of the Prime Minister's car after Mr. Gorton had left a Cabinet meeting.' ${ }^{41}$

A closer reading of official statements revealed that both federal and state governments estimated that the furore would die away. On 9 July 1968, the Age reported that,

'The [Liberal/ Country Party] Victorian Government has adopted a 'wait and see' attitude... [Cabinet] spent yesterday discussing the demonstrations... Ministers were reluctant to commit themselves to a firm course... Sir Arthur Rylah [Victorian Chief Secretary] had talks on Sunday with the Federal Attorney General. ${ }^{42}$

Despite the Age reporting that Prime Minister Gorton and Attorney General Bowen were treating 'violent demonstrations ... as a matter of urgency,' the 'urgency' had reduced to: 'By the time Mr. Bowen reports to Mr. Gorton this week he will have contacted authorities in all states'. ${ }^{43}$ It had become clear that continued media attention to these Australia wide actions risked further signification of the War and conscription and thus, further public opposition to the war. ${ }^{44}$ Government responses faded from the headlines.

In its immediate response to the demonstration, the Monash Labor Club was modest in its reportage and commentary. The event and the police response were suitably publicised in the media and the next morning's Print saw no reason to recount the event. Instead came a particularly vehement rebuke for the leaders of the pre-existing anti-war movement, CICD Chairperson, Sam Goldbloom and for one of Monash's own, Max Teichman:

The so called 'leaders' of the anti war movement showed their true colours last night. They tried to break up the demonstration and they tried to stop bail money being collected. Sam Goldbloom and Max Teichman were two of those involved. Monash lecturer Teichman demonstrated that he is in reality a mock leftist by joining the police at last night's demonstration. Teichman used a police loudhailer to try to break up the demonstration. But just about no one took any notice of him... ${ }^{45}$

Thus the Monash Labor Club signalled that it saw no impediment to airing differences in the anti-war movement stridently and publicly. This approach became a hallmark of the Monash Labor Club and the Worker Student Alliance (WSA) that it engendered. For it, keeping quiet for the sake of harmony would signal agreement with the status quo.

In the week following the July 4 demonstration, the Monash Labor Club relied on the daily press to keep the issue alive but by the end of the month, the press and government furore had begun to wane, only to reignite whenever those arrested appeared in court. The July 29 issue of Print, under the heading of 'Anyone for a Peaceful Riot?', called for support for some of those arrested at the beginning of the month: 
BEFORE I NOW

Vol. 1 No. 1

Tomorrow (Tuesday) at 10.00am., 15 people will appear in the Prahran Court... committal proceedings for rioting... They represent Monash, LaTrobe and Melbourne students, unionists and 'outsiders'... It is the mistaken belief of men like Gorton and Bolte that if a few dissenters are severely and savagely victimized then no-one will be prepared in future to stand up to the government... it is of vital importance [to be at] Prahran Court on Tuesday to demonstrate to the government that we are not prepared to submit to police state activities. ${ }^{46}$

In the Monash Labor Club's theoretical journal, Analysis, a pseudonymous Georges Sorel's article, 'Reflections on Violence,' considered the role that violence played in maintaining or resisting capitalist order. It began with sarcasm about the 4 July demonstration creating pacifists of the Premier 'Sir Henry Bolte, whose lust for the life of Ronald Ryan was all consuming,' and the Prime Minister, 'John Gorton who ... has been pleased to practice it [violence] on the Vietnamese, is shocked by a punch-up. ${ }^{47}$ 'Sorel's purpose however, was the eschewal of thoughtless activism: 'A lot of people have declared themselves in favour of the violence on July 4. Such abstract approval is anarchistic and devoid of sense'. However, 'Sorel' saw the study of state violence on the day as necessary for the progression of the radical discourse:

...endless discussion will never lead to action. But it is also true that action alone will never generate more than spontaneity... A spontaneous awareness of the state has automatically followed from the July 4 demonstration. What can only come from a previously articulated theoretical position [on state violence] is a theoretical understanding of why the state acts the way it does and why it must always do so. ${ }^{48}$

In addressing the question of violence on 4 July, not as a matter of emotion but as concerning the nature of the bourgeois state in a logical intersect of theory and practice, 'Sorel' had positioned his readers not as naïve greenhorn radicals but as already belonging to the camp of aspirant Marxists.

Sorel also saw the 4 July demonstration as a 'game changer' in that it had raised the concept of an alliance of students and workers as a necessary and practical move that the Monash Labor Club would need to make in overcoming 'new' repressive manifestation of the state: 'We can only progress to the next stage politically in working alliance with the working-class... Up to now our contact has been artificial. Now workers and students face the courts on a joint issue. ${ }^{49}$ Then, on 1 August 1968 , Print's main article announced:

Recent events have demonstrated that although students can exert pressure for social change, as an alienated group they can be rendered powerless. It is from the workers that telling pressure can come; students and workers coordinated should prove a most effective force.

With this in mind, the Labor Club has set up a sub-committee to promote increases [sic] worker-student liaison. Letters ... with offers of cooperation on broad social issues concerning both groups were sent to all Victorian Trade Unions. Later, personal representation was made to the Trades Hall... ${ }^{50}$

Some success was claimed: 'Many of the unions have expressed strong interest in the scheme, several have invited students to address meetings of their members. ${ }^{51}$

The opportunity to extend the Club's political activities beyond the campus by way of the establishment of a separate and independent organisation was provided by a serendipitous series of connections in Greville Street, in the Melbourne suburb of Prahran. By August 1968, Jill Jolliffe's experience in the Labor Club bookstall at Monash 
enabled her to establish a new bookshop named Alice's Restaurant Bookshop..$^{52}$ This was convenient for Monash Labor Club as a venue for some of their off-campus meetings and suited the bookshop by providing a supply of customers and invaluable publicity. By another fortuitous coincidence, a disused bakery had been offered for lease just two doors up the street. By December 1968, Monash Labor Club members 'posing as respectable art teachers approached the owner, took out a two-year lease, filled the show window with pottery and prints, and began to clean. ${ }^{53}$ Thus, the now infamous Bakery was established from where young, aspirant revolutionaries operated for the next few years.

\section{The demonstrating escalates}

Within the older, formal anti-war movement, the complications visited upon it by its loss of control in the 4 July demonstration led to a reassessment of the movement and of the function and nature of demonstrations. The umbrella organisation for anti-war groups was the Vietnam Co-ordinating Committee (VCC). It endeavoured to publicise, synchronize and rationalize the events planned by its constituents. By December 1968, its office bearers included David Pope and Keith Stodden from CICD, Harry Van Moorst from the newly formed Students for a Democratic Society (SDS) and Monash Labor Club members Roger Holdsworth and Dave Nadel. ${ }^{54}$

On 25 October 1968, the VCC held a demonstration outside Napalm manufacturers Dow Chemicals' head office in St Kilda Road where a dummy was to be burned as a symbol of what was happening in Vietnam. Then the remains of the dummy were to be presented to the US Consulate. Taking note of the 4 July experience, the committee had negotiated with the police and agreement was reached with the Assistant Commissioner (Traffic Operations) that the police would allow the 'napalming' of the dummy, the carrying of placards and flags, the use of its loudspeaker system and a march up the centre of St Kilda Road. However, when it came to the actual demonstration the police formed a cordon around the dummy and when it was finally lit had the fire brigade waiting to put it out; police destroyed placards and flags 'without any reason whatsoever;' the police 'using their vans and 'courtesy' cars as battering rams, forced the demonstrators to walk on the footpath;' and 'on four occasions the police ripped the cords from the loudspeakers. ${ }^{55}$

This might have been expected as the Victorian Government minister in charge of police had clearly told police to take the 'strongest possible action' and that they had handled the July 4 demonstration with 'perhaps too much tolerance. ${ }^{.56}$

Following this debacle, the VCC called for written contributions on how to proceed with demonstrations and published them in the December edition of its newsletter, Viet Protest News. Among the authors were John Lloyd for the CICD and Albert Langer for the Monash Labor Club.

Lloyd's paper recognized that demonstrations were 'not a simple release of frustration' but must be recognized as a political tool:

Demonstrations have a threefold purpose:

1. To cause a creative tension in the minds of the people who witness the demonstration...

2. ...to produce public debate ... that will lead to a change in public opinion. ...

3. ... to have the capacity of putting the government on the defensive... When the government is trying to defend its cause, it is likely to reveal its own weaknesses. ${ }^{57}$ 
When a government can direct public attention from the object of the demonstration ... to the demonstrators' methods (throwing mud-pies etc.) the initiative has been stolen from the demonstrators.

Or if the demonstrations can be easily dismissed ('those long-haired students again'), the cause is seriously impeded.

Civil disobedience may certainly be warranted on some occasions, but the plans need to be announced before the event in order to prevent placing people who are not prepared for each action in an unfortunate situation. ${ }^{58}$

In this view of demonstrations, Lloyd and the CICD ascribed a broader role to demonstrations than simple confidence building. However, in his words of caution, Lloyd downplayed the role of spectacle in attracting the media as a mechanism to generate the public debate and attention that he said was so important.

Langer's contribution, contrariwise, estimated that the problem lay not within the demonstrations themselves but within the anti-war movement itself:

[The] definite division ... between the 'moderates' and the 'militants' ... is a serious and deep division which covers the whole field of strategy and tactics and stems from differing views as to the nature of the movement and the nature of the war itself.

The moderates tend to view the war as a mistake, either for strategic reasons or because of its 'inhumane' character. They point out that the official explanations for the war are lies and base their anti-war propaganda on this and on the 'atrocities.' ...

They seek to achieve political change within the present social system - either through a strong anti-war movement putting pressure on the government, or through the election of an ALP government committed to their policies, or both. ...

... The anti-war movement in Australia is a component part of the general struggle to end American domination. Its objectives can be achieved by:

1. Making the war as unpleasant as possible for the government by disruptive demonstrations, resistance to conscription, etc.

2. Mobilising a widespread mass movement against the war by linking it with issues of direct concern to ordinary Australians, e.g. increased exploitation of Australian workers due to war expenditure, use of young Australians as cannon fodder for American interests.

... We should ... give clear-cut support to the Vietnamese people's struggle on the grounds that they are right...

Demonstrations themselves are not very important.... The role which demonstrations do play in winning mass support is by gaining publicity. ... To attract the attention of the mass media, any large mass demonstration should be as militant as possible and cause as much chaos as possible... ${ }^{59}$

Where Lloyd hoped to keep activities under control and under the threshold of social disapprobation, Langer wished to utilise the creativity of demonstrators and felt that chaos was far more effective than order. Langer viewed the practices and policies of the CICD and of the old anti-war movement as stemming from their moralistic but subservient reformism, regarding the causes of the war and of their continual adjustment of anti-war activity to the needs of the ALP. This was a strongly held position of the Monash Labor Club. 
The differences between Lloyd and Langer's contributions have clear implications. In the words of Scalmer, 'the utility of the more unadorned and simple forms of staging was also being undermined.... Organisers of vigils and rallies came to accept that their actions would not now produce a 'spectacular outcome'.60 The VCC committee's report of the 25 October demonstration stated,

We have tried cooperation with the police - it doesn't work! ... they obviously prefer to push us around rather than cooperate with us... We are not going to be pushed around any more. To prevent violence and disorder in future demonstrations the VCC will provide its own police force and will request the regular police to keep clear of the demonstrators. ${ }^{61}$

The VCC, at its 21 November meeting, adopted a set of general principles regarding the conduct of demonstrations including:

1. That no precise form of demonstration be excluded....

2. Before a demonstration the plans and objects should be set out for ... component bodies of the VCC and the resulting consensus should be the program

3. That the appointed leaders and marshals are then answerable to the accepted plans and objects of the demonstration.

This was a signal that the old practice of holding centrally organized vigils and static, celebrity meetings in Assembly Hall was at an end. The form of demonstration would have to be argued out on the floor of open meetings rather than in executive gatherings of the like-minded.

\title{
Conclusion
}

In practice, the VCC's willing organisation of the napalming of a dummy with a repeat march to the US Consulate, and its castigation of the police attack upon them, signified that the older movement had come some way to accepting disruption as a valid means of protest. The practice of peace luminaries calling upon their middle class followers to 'happy clap' the war away was at an end. The newer generation of protesters' interminable politicking, which, to some, seemed to be dangerous and mindless activism, had forced the general anti-war movement to rethink its claim to social responsibility. From the mild-mannered staging of public exhibitions of its pacific credentials, it refocused to promote acts disruptive of 'business as usual' in defiance of the threat of police action against it. This was the refocusing that made the achievement of the mass disruption of the Vietnam Moratorium possible.

\author{
Nicholas Butler | PhD \\ CRCAH, Federation University Australia \\ Email: nickbutler106@bigpond.com
}

Nicholas Butler, a member of the Before/Now editorial collective, completed his PhD, Anti-War, Radical Youth Revolt, Victoria, 1965-1975, at Federation University. He was an activist in the 1960s and 1970s radical youth movement and in the Vietnam War Moratorium movement.

This research is supported by an Australian Government Research Training Program (RTP) Fee-Offset Scholarship through Federation University Australia. 


\section{References}

Armfield, Hugh. 'Canberra sit-in puts 61 in gaol.' The Age, May 20, 1968.

Dawson, Jack. 'Troopers ride down anti-war rioters,' The Age, July 5, 1968.

Draft Resistance Movement, Melbourne University Pacifist Society, National Mobilization, Leaflet advertising the impending mobilization event. April 1968.

Hamel-Green, Michael. For All Demonstrators, Melbourne, National Mobilization Committee, May 1968.

Irving, Nick. 'Couldn't we actually try and do this in Australia? Reading the Vietnam Moratorium in its do this Global Context.' in Fighting Against War, Peace Activism in the Twentieth Century, edited by Phillip Deery and Julie Kimber, 2015 Conference of the Australian Society for the Study of Labour History, Melbourne, Leftbank Press, 2015.

Mansell, Ken. 'The Yeast is Red.' in Disobedience, edited by Emily Floyd and Ken Mansell, Melbourne, Monash University Museum of Art, 2013.

Monash Labor Club. Analysis, Clayton, Victoria, July 1968.

Monash Labor Club. Print, Clayton, Victoria, July 1968.

National Mobilization Committee, FOR ALL CIVIL DISOBEDIENCE PARTICIPANTS, Canberra, May 19, 1968.

Perry, Paul Francis. The Rise and Fall of Practically Everybody : an account of ... political activity at Monash University, 1965-72, Balaclava, Victoria, P.F. Perry, 1973

Scalmer, Sean. Dissent Events, Protest, the Media and the Political Gimmick in Australia, Sydney, UNSW Press, 2002.

Canberra Times. 'De Gaulle Takes Over Troubles.' May 20,1968.

Canberra Times. ' 45 arrests in anti-US riots.' July 5, 1968.

The Herald. 'Rylah to police: you must get tough.' Melbourne, July 5, 1968.

Sydney Morning Herald. 'Mounted charge ends mass student riot.' July 5, 1968,

\section{Notes}

1 Sean Scalmer, Dissent Events, Protest, the Media and the Political Gimmick in Australia, Sydney, (Sydney, UNSW Press, 2002), 64-65.

2 Scalmer, Dissent Events, 56.

3 Monash Labor Club, 'Editorial,' Analysis 1, (July 1968): 1.

4 'Son of Print,' Print, (29 July 1968): Underscore in the original.

5 Paul Francis Perry, The Rise and Fall of Practically Everybody: an account of political activity at Monash University, 196572 (Balaclava Victoria, P.F. Perry, 1973): 1. By 1968 the club had over 300 members.

6 Ken Mansell, 'The Yeast is Red,' in Disobedience, eds. Emily Floyd and Ken Mansell (Melbourne, Monash University Museum of Art, 2013), 32.

7 Draft Resistance Movement, Melbourne University Pacifist Society. National Mobilization, Leaflet advertising the impending mobilization event. April, 1968, 2.

8 Michael Hamel-Green, For All Demonstrators (Melbourne, National Mobilization Committee, May 1968), 2. A set of instructions for participants. Downloaded from reasoninrevolt.net.au on 7 October 2016.

9 Hamel-Green, For All Demonstrators, 1.

10 Hamel-Green, For All Demonstrators, 2. Note that the '20 others' were not named by the organisers.

11 Michael Hamel-Green, For All Demonstrators, 3.
12 National Mobilization Committee, FOR ALL CIVIL DISOBEDIENCE PARTICIPANTS, (Canberra, May 19 1968). Instruction leaflet for participants in the National Mobilization against conscription, downloaded from reasoninrevolt.net.au on 7 October 2016.

13 'Obliging police arrest 69,' Canberra Times, May 20, 1968, 1.

14 'Obliging police arrest 69,'

15 'Obliging police arrest 69,' 7.

16 'Obliging police arrest 69,' 7.

17 Hugh Armfield, 'Canberra sit-in puts 61 in gaol,' The Age, May 20, 1968, 1.

18 Scalmer, Dissent Events, 56.

19 Scalmer, Dissent Events, 65.

20 Melbourne, Monash plus LaTrobe University which first enrolled students in 1967 and by 1968 had a Labor Club of its own.

21 Scalmer, Dissent Events, 65.

22 Vietnam Day Committee, leaflet advertising rally, July 4, 1967.

23 'Reassurance on U.S. link,' The Age, July 5, 1967, 4.

24 Print, Monash Labor Club, Monash University, July 4, 1968, 1. (Emphasis in the original.) 
25 A tombowler is a very large marble about the size of a table tennis ball.

26 'Persons of Interest,' Australian Security and Intelligence Organisation, Vietnam Coordinating Committee, July 4 Demonstration, US Consulate, Commercial Road, Section of film smartstreetfilms.com.au, Downloaded from https://www.facebook.com/personsofinteresttheasiofiles/ on November 28, 2016.

27 Jack Darmody, 'Troopers ride down anti-war rioters,' The Age, July 5, 1968, 1.

28 'Fine Not Paid- Student Gaoled,' The Herald, July 5, 1968, 3.

29 Darmody, 'Troopers ride,' 1.

30 Darmody, 'Troopers ride,' 1.

31 'Mounted charge ends mass student riot,' Sydney Morning Herald, July 5, 1968, 1.

32 The Herald, July 5, 1968, 3.

33 Melbourne had three major daily newspapers; The Herald-Sun with The Sun, a morning tabloid and the Herald, an afternoon broadsheet. The Age, was a morning broadsheet.

34 The Age, Melbourne, July 10, 1968.

35 Yes, Melbourne had a City Square in 1968, on the corner of Swanston and Collins Streets. It is now (2019) the site of an hotel and the excavation for an underground railway station.

36 '45 arrests in anti-US riots,' Canberra Times, July 5, 1968, 1.

37 The Herald, July 5, 1968, 3.

38 The Herald, July 6, 1968, 9. (Underlining in the original.)

39 The Herald, July 6, 1968, 9.

40 Hugh Armfield, 'PM acts to 'tame' protesters,' The Age, July $9,1968,1$.

41 Armfield, 'PM acts to 'tame' protesters.'

42 'Cabinet talks on flare-up here,' The Age, July 9, 1968, 1.

43 Armfield, 'PM acts to 'tame' protesters.'

44 For example: In 1967, when the deployment of an extra battalion to Vietnam was announced, ... An opinion poll revealed that 46 percent of the electorate disapproved of the decision, 17 percent were undecided. Only 37 percent were in favour. Department of Veteran Affairs, https://anzacportal.dva.gov.au/history/conflicts/ australia-and-vietnam-war/events/public-opinion

45 Michael Hyde, 'Which Side Are You On?' Print, July 5, 1968, 1.

46 'Anyone for a Peaceful Protest?' Print, July 29, 1968.

47 Georges Sorel, 'Reflections on Violence,' Analysis (July 1968): 1. 'Georges Sorel' is a pseudonym.

$48 \mathrm{~S}$ orel, 'Reflections on Violence,' 2.

49 Sorel, 'Reflections on Violence,' 4.

50 'Theory + Practical Experience = Effective Solidarity,' Print, 1968, August 1, 1.

51 'Theory + Practical Experience = Effective Solidarity,' Print,

52 Mansell, Disobedience, 34.

53 Mansell, Disobedience, 37.

54 John Layfield, 'Secretary's Report,' Viet Protest News, Number 19, Parkville, Melbourne, Vietnam Coordinating Committee, December 1968. Downloaded from http://www.reasoninrevolt.net.au/objects/images/image_v iewer.html?d0726,8,1,S,

55 'Demonstrations - Oct. 25,' Viet Protest News, Number 19, Parkville, Melbourne, Vietnam Coordinating Committee, December 3, 1968.

56 'Rylah to police: you must get tough,' The Herald, Melbourne, July 5, 1968, 1.

57 John Lloyd, 'Demonstrations,' Viet Protest News, Melbourne, December 4,1968, 5.

58 Lloyd, 'Demonstrations,' 5.

59 Albert Langer, 'Demonstrations,' Viet Protest News, Melbourne, December 1968, 6-8. Inverted commas and capitalizing are in the original.

60 Scalmer, Dissent Events, 49.

61 Vietnam Coordinating Committee, 'Secretary's Report,' Viet Protest News, Melbourne, December 1968, 3. 